\title{
Alan Paton's writing for the stage: towards a non-racial South African theatre
}

\author{
Hermann Wittenberg
}

\section{Introduction}

It would not be an exaggeration to assert that no South African playwright in the 1950 s and 1960 s received as much international attention and recognition as Alan Paton, until eclipsed by Athol Fugard's emerging career. Paton's own plays and musicals, and the stage adaptations of his novels, had some extensive and successful runs on Broadway in New York, and also played to packed houses in South Africa. Some highly acclaimed artists, ranging from the German avantgarde composer Kurt Weill to South Africa's jazz musician Todd Matshikiza, helped to bring his work to the stage. Yet Paton's theatrical work has received surprisingly scant attention from critics, which is all the more remarkable, given the author's prominence as one of South Africa's most well-known writers. Like his novels, Paton's plays are not simply light human dramas or romantic comedies as much colonial theatre at the time, but serious works that were deeply concerned with the socio-political issues facing South Africa under apartheid. As Paton once put it, he was never interested in "writing a 'jolly good fellow' sort of play." 1 Three of his major plays were written and performed in a crucial period of South African history: the Sharpeville massacre, the implementation of the Group Areas and other cornerstone apartheid acts, the treason trials, and the declaration of the republic.

There are possibly four interrelated reasons for Paton's relative obscurity as a playwright today that will be explored more fully in this article. Firstly, only one of his major plays, namely Sponono, has been published and his other play scripts are not easily available for study. In some cases, the plays are fragmentary and incomplete, or have survived only in the form of a single hand-written manuscript. Secondly, Paton's plays are of uneven theatrical merit, and while there were some highly successful productions, in other cases flawed scripts or staging problems contributed towards box office failure. Thirdly, Paton had a strong internationalist orientation with particularly strong links to Broadway in New York. Instead of South Africa, where there were increasingly obstacles put in place to prevent multi-racial casts and audiences, Paton's own plays and the plays made of his novels, often had more significant international runs. One of his plays premiered in Lusaka. In South Africa, Paton's works could not be performed in most mainstream municipal theatres or on the stages under the auspices of the state-controlled performing arts councils. This has possibly 
contributed to less of an awareness locally of his theatrical work. Lastly, and perhaps most importantly, Paton's writing and his liberal politics came under sustained negative criticism from leftist and black critics, particularly in the late 1970 and 1980 s as radical and Marxist critiques began to emerge in South African academia. Paton's depiction of naive rural simplicity in Cry, the Beloved Country, the work with which his name has become synonymous, then became an easy target for a many critics, ranging from Nadine Gordimer and J.M.Coetzee to Es'kia Mphahlele and Dennis Brutus. ${ }^{2}$ During the intensification of the struggle after the Soweto uprising of 1976 and a polarisation of South African politics during the states of emergency in the 1980s, the word "liberalism" gained a distinctly pejorative meaning. As chairman and president of the Liberal Party, Paton's literary work became more closely identified with liberalism than that of other liberal white writers, such as Fugard.

The political unfashionableness of Paton has however obscured his considerable contributions towards building a non-racial South Africa. One such example was his leading role in establishing the Defence and Aid Fund that not only helped the accused in both Treason Trials, but also played an important role in defending anti-apartheid activists well into the 1990s. It will be argued that, like Paton's political work in the non-racial Liberal Party, his plays were intended to promote social change and contribute towards the building of a non-racial society. Indeed, according to Vanzanten Gallagher's judgment, Paton's writing can "now become a postmodern symbol of the postcolonial South Africa" (1997: 387), and is quoted approvingly by Nelson Mandela, Mamphele Ramphele and other leading figures in a new South Africa. In this revisionist context, it is worthwhile and timely to re-examine Paton's plays in the context of their time, and in so doing provide an overview and assessment of his entire theatrical corpus, something that has not been attempted before in any other academic study. Dennis Walder's assertion, namely that the performance of Fugard's The Blood Knot on 3 September 1961 was "the first time, a white man and a black man appeared together on stage" in a South African play (1984:1), is clearly not tenable if we look at Paton's pioneering work in non-racial theatre more closely.

As far as can be ascertained from autobiographical records as well as the manuscript collections of the Alan Paton Centre (APC) in Pietermaritzburg, Paton wrote four major plays, as well as a number of shorter, occasional performance pieces. Given the fact that his demanding public role as a Liberal Party politician allowed him to write only one further novel (Too Late the Phalarope) after Cry, the Beloved Country, his plays must now be considered a more significant part of his literary output than has hitherto been acknowledged by Paton scholars. Indeed, Paton's first major literary work, his early play "Louis

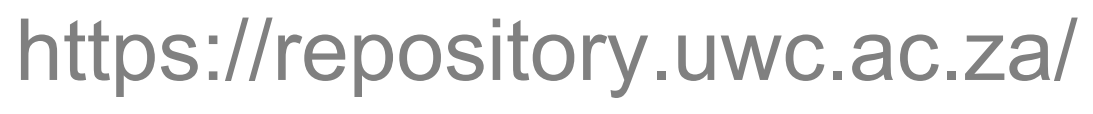


Botha" (1932), shows that he reached creative maturity as a playwright long before he became a famous novelist. "Louis Botha" is an important text and a remarkably accomplished drama written in the tradition of the Anglo-American "well-crafted" play and will be considered briefly before discussing the three mature plays in more detail: "Last Journey" (1959), and the musical plays "Mkhumbane" (1960) and Sponono (1962). As already indicated, only Sponono has been published, first by Scribners in New York (1965), followed by a local David Philip edition in 1983. The other three plays remain unpublished in manuscript format. They were part of Paton's voluminous literary legacy that his widow, Anne Paton, donated to the University of Natal in Pietermaritzburg in 1989, where they are now preserved in the archives of the Alan Paton Centre.

Furthermore, it is worth noting that both Paton's novels were repeatedly adapted for the stage, with at least three stage versions of Cry, the Beloved Country as well as two film adaptation (Zoltan Korda, 1951; Darrel Roodt, 1995). Paton himself wrote the screen play for Korda, and was involved in the filming process. The musical adaptation of the novel, titled "Lost in the Stars", was a collaboration between the librettist Maxwell Anderson and the German jazz composer Kurt Weill, who had achieved musical fame with Bertholdt Brecht's "Three Penny Opera". Paton did not appreciate the distortion of his novel (1990:20), but the musical was nevertheless a resounding commercial success on Broadway 3 that brought him much recognition and paved the way for the later staging of Sponono. "Lost in the Stars" was even adapted for a major feature film of the same title in 1974. A second stage version of Cry, the Beloved County by Felicia Komai (1954) was more faithful to the original, as was Roy Sargeant's recent South African production. Sargeant's play opened at the Grahamstown Festival in 2003, celebrating the centenary of Paton's birth, and went on to tour major centres in South Africa. Sargeant had previously also written a screenplay of Paton's novel Too late the Phalarope. Another version of this novel, by the American Robert Yale Lippt, had a moderately successful run on Broadway in October 1956. It is clear then by the large number of adaptations, that Paton's writing proved highly attractive to both dramatists and filmmakers.

\section{Early and minor plays}

Among the shorter dramatic pieces from Paton's pen were light-hearted skits such as "A Light Comedy" (1949) that dealt with the frustrations of power outages (hence the pun in the title). The Patons regularly invited friends from all races to their home in Kloof (a suburb of Durban) and during these large and lively social gatherings, satirical poems were often recited and impromptu plays performed. One of the more serious and intriguing texts emanating from this corpus of home performance pieces is a short play titled "Chess in Yugoslavia" (1961) that

$$
\text { https://repository.uwc.ac.za/ }
$$


prompted the Huisgenoot to publish a photograph of the audience with the disparaging title "Waar Wit en Swart Saam Flankeer" (17 November 1961). "Chess in Yugoslavia" is an entertaining one-act play that pokes satirical fun at the corrupt and absurd machinations of apartheid bureaucracy. It gives us a good indication of Paton's skills as a politically engaged playwright. The plot concerns three chess players, an Indian, an African and a white man, who endure Kafkaesque frustrations when applying for a passport to attend a chess tournament in Yugoslavia. A representative excerpt follows:

Investigator: Gits, man, you don't know what you're asking. Why don't you ask for something easier? (He is torn in two) You know, I do what I can for the Indian people. Sometimes I get their passports through in as few as six months. But they make it easy for me. They ask to see temples, and study Yoga, and see grand-parents, and buy goods. But not to play chess in Yugoslavia. (Earnestly) And why chess, Mr Boovalingham? Why pick on a European game? Haven't you got any Asiatic games?

Boovalingham: (Coldly) Chess, is, as you call it, an Asiatic game. (1971: 190)

Written with an economical, light touch, Paton's black humour captures the stereotypical narrow-minded Afrikaner bureaucrat perfectly, while at the same time ridiculing the injustice and preposterousness of racial classification. The three characters' names, namely Peter Boovalingham, Jordan Ubani and Leo Kupansky are thinly veiled references to three of Paton's close friends and fellow Liberal Party stalwarts, namely Pat Poovalingham, Jordan Ngubane and Leo Kuper. It is very likely that they also played their respective parts in the original performance, with Paton casting himself in the central role of the Investigator. Paton's fluency in Afrikaans would have enabled him to play the Afrikaner apartheid apparatchik very convincingly.

In "Louis Botha", written anonymously under the penname "Natalian" almost 30 years earlier, Paton created an ambitious play in five acts that not only shows him as a skilful dramatist, but also gives us an early insight into his use of theatre as an instrument to effect social change. The play revolves around General Louis Botha, South Africa's first Prime Minister, whom Paton admired. In the play, Paton depicts him as a model South African who transcends narrow ethnic boundaries in a flawed attempt to build a unified South African nation. The play opens with a scene set in the bitter final weeks of the Anglo-Boer war, in the darkest hour of the Afrikaner, and ends on the eve of the First World War, with

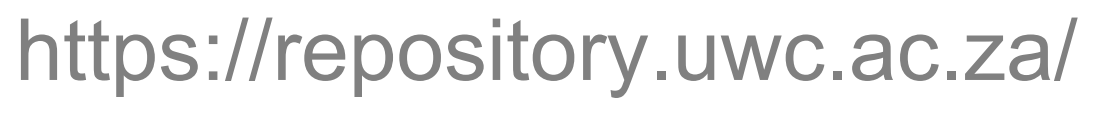


Louis Botha as Prime Minister of the Union of South Africa, but estranged from his own people, having had to put down a rebellion in which his adoptive son is killed. It is essentially a tragedy in which Botha's vision for a united nation of South Africa is pitted against a narrower, ethnically defined Afrikaner nationalism fuelled by bitter memories of military defeat, the horrors of the concentration camps and the loss of independence. Botha castigates Boer narrow-mindedness as follows: "They will not rest till they build their race again. But it is not a race I would build, but a nation". Instead he has an alternative vision of South Africa:

I see - I go on seeing - a new country, where English and Dutch live in peace, where the Englishman has his King and his tradition, and the Dutchman has his freedom. And I will not yield it for Englishman or Dutchman. Let the Englishman talk of my slimness, and the Dutchman of my treachery, but I will not yield it. (PC 1/3/4)

The play however ends with Botha isolated and dejected, but still persevering with his vision. His equivocal last words are: "What do I see? I see a world lost in darkness and mist. But who can tell what tomorrow may bring?”

"Louis Botha" contains some powerful scenes that show Paton's sure grasp of dramatic effect, as we can see in the understated pathos of the opening scene. Carel, a young boy, has just ridden through enemy lines to reach the Boer field headquarters with a message for his father:

Botha: (gently) So you are Paul's son? (he puts out his hand)

Carel:

Botha:

Carel: 4rth Boer:

Botha:

Carel:

Botha:

Carel: (taking the hand with obvious hero-worship) Yes, Oom Louis.

(quietly) Where are you from, my son?

From Bloemfontein, Oom Louis.

And alone, General.

That was brave. You have a message, my son?

(in a low voice, lowering his head) For my father, Oom Louis. (very gently) I am here in your father's place, my son.

(raising his head) It is a hard message. From the Camps. Our mother is dead. (his lip quivers) (PC 1/3/4)

In the next few lines, when Botha tells his men in an aside "Not a word to the boy", the unsaid implication is that Carel's father has just been killed in action. With a remarkable economy and poignancy, Paton here conveys the military

\section{https://repository.uwc.ac.za/}


hopelessness of the "bitter einder" last days of the war, as well as the despair of the concentration camps.

Paton wrote the play in 1932 and revised it for entry in a competition in 1935. Peter Alexander, Paton's biographer, argues that Paton wrote it principally to impress J.H. Hofmeyr, ${ }^{4}$ who at the time was one of South Africa's most powerful politicians as Minister of the Interior, Education and Public Health. Paton regarded Hofmeyr not only as a friend and mentor, but also as the embodiment of Botha's nation-building ideals, and hoped that he would one day succeed Smuts as Prime Minister. Hofmeyr liked the play and it was also read approvingly by the British actress Sybil Thorndike. It did not however find favour with the competition adjudicators who thought that it was "under the stipulated playing time of two hours", had "too little action" and furthermore ended "on the wrong note" 5 . The adjudicators may well have been looking for a less serious or political play, as seems probable when looking at the light-hearted titles in the final shortlist: "For a mess of pottage", "Yesterday's fruit", "Malay fever" and "Let they say”.

After the negative competition outcome, Paton appears to have abandoned the play and immersed himself in the challenges of running Diepkloof, the Johannesburg reformatory for black offenders of which he became principal in 1935. There is no record of any performance of "Louis Botha", but it is nevertheless a poignant drama that shows Paton's deep empathy for the Afrikaners and the tragedy of their internal political struggles. Paton's empathy for Afrikaners found ultimate expression in his participation in the Groot Trek celebrations in 1938. After arriving at the Pretoria festivities in an ox wagon and sporting a beard, he soon however became thoroughly disillusioned by the manner in which Afrikanerdom had been hijacked by fanatical nationalist interests. ${ }^{6}$ Throughout his life he would from now on consider himself an implacable foe of Afrikaner nationalism, clashing repeatedly with Verwoerd and other nationalists.

Paton's alternative and liberal vision of South Africa, as expressed in "Louis Botha", is however limited by an exclusive concern with white nation-building. To be fair to Paton, an awareness of racial injustice among white South Africans was rare in the 1930s and 1940s, even among progressive and educated elites. As Paton candidly admitted in his autobiography, he at this time still "clung to the irrational idea that one could maintain white supremacy and yet be just" (1986: 240). Paton's politics however soon began to change as a result of his experiences with juvenile black offenders at Diepkloof, as well as his participation in an Anglican commission that had been tasked "to define what it believed to be the

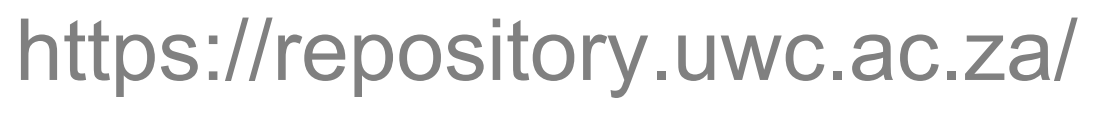


mind of Christ for South Africa" (1986: 238). By the time that he wrote Cry, the Beloved Country in 1946, Paton was firmly committed to the principles of nonracialism and an inclusive South African nation that gave black and white equal citizenship. Although "Louis Botha" reflects Paton's naïveté of racial issues at the time, the play gives us an important early insight into the themes that pervade his later works: the need for reconciliation across ethnic, cultural and linguistic divides, and the liberal vision of an inclusive, socially just South Africa.

\section{Last journey}

It would take Paton more than 25 years to write another major play. This long hiatus is partly explained by his success as a novelist, but also, later, by his growing pre-occupation with national politics that left him very little time to write. Paton became national chairman of the Liberal Party in 1956, during a particularly tense political period in which the increasingly rigid National Party government imposed its programme of grand apartheid. The previous year, 1955, had seen the bitterly contested destruction of Sophiatown, followed by the Kliptown People's Congress and the protracted first treason trial. In this difficult period, Paton's Liberal Party was the target of a sustained government campaign, before finally being forced to disband. Its leaders suffered imprisonment, harassment and banning. Paton himself was spared jail, due to his international profile, but he was under continual police surveillance and his passport was confiscated. His friends and party colleagues were worried about the effect his political responsibilities as party leader were having on his writing, and he was persuaded to resign as head of the Liberal Party in 1958 although he remained deeply involved in its political work (Paton 1990:175). It was in this situation that Paton, then in his mid-fifties, produced his later plays: no longer charged with the responsibility of day-to-day party management, he expressed his political concerns and ideas more obliquely through his writing. Although his major preoccupation was his biography of Hofmeyr, this was also a productive period in which Paton wrote plays for multiracial casts and audiences. An examination of these plays will show that he was deeply concerned with the racial politics of South Africa, and tried to address these problems in various ways.

In 1958, Paton began working on the play "Last Journey", a historical drama about the death of the British explorer and missionary David Livingstone. The play was no doubt partly inspired by several African journeys Paton himself undertook in this period. In 1956 he joined a quixotic expedition into the Kalahari (see Wittenberg 2005) and in 1958, Paton, together with his family, undertook a grand tour of central Africa. Travelling in his huge, red Pontiac motor car, they drove north, taking in Rhodesia, Zambia, Congo, Rwanda and Uganda.7 "Last Journey" is interesting in the sense that it does not deal with the

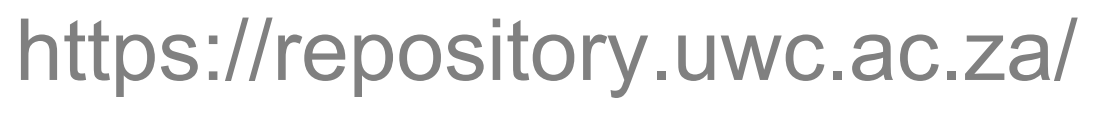


character of Livingstone himself, but with his loyal African servants who undertook an epic and treacherous 1500 mile journey to bring the missionary's remains back to the coast. There is hardly a scene on the play in which Livingstone's wrapped body is not centre-stage, but most of the action of the play is carried out by a large cast of African characters, in particular Livingstone's servants Susie and Chuma. The heroic white colonial explorer figure is thus simultaneously present and absent, a postcolonial irony that Paton may not have recognized.

"Last Journey" opened in the Waddington Community Centre in Lusaka on 3 May 1959. When asked why he had chosen Lusaka for the premiere, Paton explained that "Livingstone, the subject of my play, was more closely connected with this country than any other". But he also made it clear that he was "very strongly opposed to a segregated audience" and that it "would be extremely difficult to produce a play with a mixed cast as this calls for in the Union."8 Paton's choice of venue was also influenced by his keen interest in the Waddington Club which was open to "members of any race, over the age of 18 , duly proposed and seconded, and approved by the Committee". Its constitution explicitly stated that "No person shall be barred from membership of the Waddington Club solely on grounds of race, colour or creed". 9

Paton's strong non-racial views not only influenced the place where his play was going to be performed, but also shaped his handling of the subject matter. Livingstone had died in 1873 and what Paton found "completely absorbing" 10 were not so much the missionary's spectacular discoveries and exploits, but an astonishing act of self-sacrificing loyalty that was shown by Africans to the white man. In an unpublished commentary on the play he asks: "What made them undertake this tremendous task? Was it loyalty to Livingstone? Was it because they knew that Livingstone was a famous man, and thought that he should be buried in his own country? Or was it love for him that they wanted him to lie amongst his own people?" Writing in a country that was increasingly being torn apart by racial injustice and oppression, Paton was clearly struck by an act of selfless devotion and sacrifice shown by Africans towards a white man, something that would have seemed increasingly unfeasible in South Africa at the time.

In his essay, Paton also discusses the tension between his act of "imaginative recreation" and giving a "historically truthful" account of events. Paton was especially troubled by the attitude of the white men in the story, particularly the heartlessness and arrogance of Captain Prideaux who received Livingstone's body in Bagamoyo and whisked it off to Zanzibar, leaving Susie and Chuma standing empty-handed and rejected on the beach. They had after all carried their master's

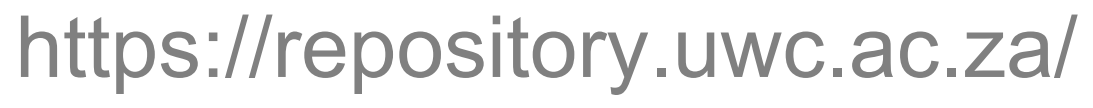


body for nine months on an arduous journey through treacherous terrain, at the cost of several lives to their party. Paton writes of his "white South African writer's difficulties" in dealing with Susi's and Chuma's hurt, and is at pains to ameliorate the affront by inventing an act of symbolic atonement carried out by a more sympathetically depicted Captain Murphy. One suspects that for Paton the real drama of the Livingstone material lay not so much in the story of an epic journey, but in the way the colonial divide between Africans and whites could be imaginatively overcome through an act of reconciliation and reparation. Yet despite bending the historical record by balancing Prideaux's arrogance with Murphy's apologetic compassion, Paton again risked ending a play on the wrong note. This will become evident when looking at the mixed reception of "Last Journey".

Most critics were inclined to be positive about the play, for example a review in the Sunday Mail, titled "Alan Paton Play is Top Class". It called the play a "moving experience" and a "bold step towards establishing an indigenous theatre", and lauded "the simplicity of the play and the refreshing spontaneity in the interaction on the stage of 28 African, 14 European and two Eurafrican players" (3 May 1959). Ms Gertrude Miles, who was the Northern Rhodesian drama festival adjudicator, was however unimpressed by the acting. In an article "Theatre for Africans 'a right step" (The Northern News, 12 May 1959), she called Paton's play "a most wonderful venture" but critiqued the length of the performance that was drawn out even further by the amateurishness of the African cast: "They did one thing at a time - either they spoke or moved." She conceded patronisingly though that "the African" had a "natural aptitude for acting". Another review, titled "Paton play has a simple moving sincerity" in the Central African Post (4 May 1959), was largely sympathetic and praised the establishment of "an interracial theatre", but also pointed out "structural shortcomings" and lack of "dramatic compulsion". In the words of this review, "Last Journey" was decidedly "not another Cry, the Beloved Country". Looking at the impact of the play on the audience, the critic noted that "the final applause was surprisingly polite and neither the author nor the producer, the Rev. John Houghton, was called". The critic then speculated as to the reasons for the lukewarm reception:

Perhaps the audience was unresponsive to the 'message' of the play. Perhaps some found in it an answer they were unwilling to accept. Perhaps others found 'some mockery of myself' in the vague bungling pomposity of British colonial officialdom typified by Acting-Consul Prideaux.

\section{https://repository.uwc.ac.za/}


For the largely white colonial audience in Lusaka, the final "message" of the play, namely that Africans deserved to be treated with more respect and dignity, especially when having performed extraordinary service to whites, was perhaps uncomfortable. As one reviewer suggested, Paton's depiction of a callous colonial official might have been construed as a "mockery" of their own values. Paton's play certainly stood out markedly from the usual theatrical offerings in colonial Zambia at the time, if one looks at some of the other plays performed that year: "Oklahoma", "Two Dozen Red Roses", "Hamlet”, "Murder in the Red Barn”, and so on. Paton seems to have been partially aware of the danger of alienating his audience, as notes on the role of Lt. Cameron reveal. Cameron had tried to dissuade Susi and Chuma from completing their journey, and Paton was anxious to not present him as a villain:

[Cameron] should not be portrayed as a pompous caricature of an English gentleman; this would have the effect of embarrassing and perhaps antagonising the white members of the audience, and of amusing the African members, perhaps at some point where amusement would destroy a serious dramatic intention. (PC 1/3/6/2)

In the final lines, Paton had tried to end the play more positively, when Murphy tries to make amends:

Murphy: (in a low voice) Susi, I do not know what to say

Susi: (also in a low voice) There is nothing to say....

Susi: $\quad$ Listen to me, Bwana. We had a work to do, to take the body from Ilala to the sea. The work is done, and I am satisfied.

Chuma: (angrily) I am not satisfied. (to Murphy) Are you satisfied?

Murphy: No, I am not satisfied. When I go to England, I shall ask why you are not there. I shall mask if the people of England did not want to see you with their own eyes. (Murphy speaks eagerly) I shall tell them that I saw you with my own eyes. My children - if I have any will know about every one of you and the journey that you made. (PC 1/3/62)

Murphy then gives Susi and Chuma Livingstone's sextant as a symbolic gift of reparation (an act invented by Paton), and expresses the wish to come back to

\section{https://repository.uwc.ac.za/}


Africa again. The play ends with an exchange that affirms the fundamental equality of African and whites and the need for reciprocity:

Susi: We will receive any man. There is one condition only.

Murphy: What is that, Susi?

Susi: $\quad$ He must want to be received. (PC 1/3/62)

It is not entirely clear how aware Paton was of the fact that he had antagonised his Lusaka audience with a play that was less about Livingstone than about the fraught nature of colonial race relationships, but he responded to criticism of the play's excessive length and its plodding nature by undertaking major revisions. Paton told a reporter that he had high hopes of having the play produced in the United States, "where there is a great need for plays in which negro actors can take major roles"11. There are altogether then three versions: firstly, the play written for the Lusaka performance, with some minor changes undertaken during rehearsal. This script has only partially survived. Secondly, there is a substantially revised version, probably post-Lusaka, in which several scenes were omitted or shortened, and new bridging sections written. The discarded scenes, plus the newly written bridging scenes are available, but unfortunately not the major bulk of the rewritten retained material. "Last Journey", in either of these two surviving versions, is therefore not a complete play, with important sections lost.

The third version of the Livingstone material is a completely new play text, incorporating only minor sections from original. Titled "David Livingstone. Being a dramatic representation of the life of the great missionary and explorer, designed for performance in churches", this play is has a much reduced and allwhite cast, with most lines in verse spoken by a narrator. The play is also not primarily about Livingstone's death, but presents episodes depicting various important events in his life. The script is not a hagiographic account of Livingstone's life, and Paton does not disguise his faults, chief of which was his fatal obsession with Africa:

Narrator: The missionary turned explorer!

The missionaries head turned too because

The Queen had given him five and twenty pounds

For finding Lake Ngami! And his wife

And children sacrificed to his new passion,

Exposed to fevers and wild beasts and men

https://repository.uwc.ac.za/ 
And all the pestilence of Africa!

His friend Sechele to be jettisoned

For some more powerful chieftain in the north! [typo in this line]

The dry and arid land of the Bakwains

To be exchanged for Makololo country

Because a man liked rivers! With what joy

He first beheld Zambesi, Queen of all,

Flowing full-bodied and wide breasted to the sea,

Jewelled with islands, tressed with palms and trees ... (PC 1/3/6/5)

Paton here chastised the way Livingstone abandoned his wife and children for a new mistress, namely a feminised and eroticised Africa. Africa, he wrote in his essay, was Livingstone's "belle dame sans merci. When there came a choice between her and his wife and family, he did not dither about it." The play's stage directions (e.g. "Light goes on in the nave") clearly show that Paton had a church performance in mind, with the congregation included in the script:

Narrator: $\quad$ For all the wonders of Africa, its waterfalls and mountains

Congregation: We thank thee Lord

Narrator: For its birds and beasts and flowers, its diversity of races

Congregation: We thank thee, good Lord. ( $\mathrm{PC} 1 / 3 / 6 / 5)$

It is not clear that this play was ever performed, and Paton makes no mention of it in his autobiography. We may speculate that Paton, a committed Anglican, developed the church version because he was still attracted to the material, but that it was less contentious politically in this form and more likely to be performed in this more limited theatrical format. It is plain however that "Last Journey" and its derivatives were not a major success. ${ }^{12}$

\section{Mhkumbane}

Paton's next equally ambitious foray into theatre, his first musical, was more unambiguously successful. With a large all-black cast, a lively story line and attractive songs composed by Todd Matshikiza, "Mkhumbane" appealed to a wider audience. Matshikiza had previously achieved fame with the musical "King Kong", and had been recommended to Paton. Although the musical could be critiqued as an "appropriation of black performance" (1991: 70), to use Martin Orkin's phrase, "Mkhumbane", directed by Malcolm Woolfson, created significant opportunities for black artists, and also helped to sustain non-racial social spaces in South Africa. The significance of "Mkhumbane" (the name of a "black spot" African shack settlement in Cato Manor) lay not so much in its fairly conventional story line and content, but in the way it brought together black and

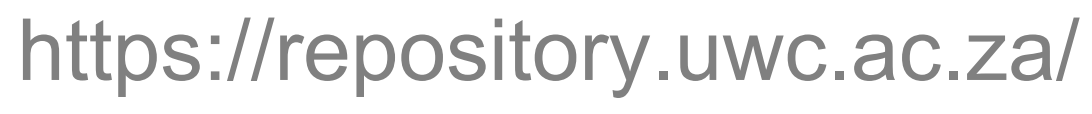


white South Africans against a background of increasing state-enforced segregation. This was not only true for Paton's and Matshikiza's personal collaboration (he stayed in the Patons' home for several weeks), and the rehearsals which brought almost 150 black amateur actors and singers into sustained contact with white theatre professionals, but also for the public performances in front of multiracial audiences. As Paton himself put it, " 'Mkhumbane' was specifically written to give a chance for the black people of Durban, teachers, domestic servants, artisans, taxi-drivers, to get up on the stage and talk and dance and sing" (1990:195). Paton's commitment towards nonracialism was also reflected in the fact that he had dedicated the opening night to the South African Institute of Race Relations (SAIRR), who was also to receive the box office proceeds.

The political circumstances of the play's opening run in Durban's City Hall were dramatic, and it is difficult to imagine any other major South African theatrical production taking place in a more fraught situation. Paton tells the story in his autobiography, and it is well worth recounting. "Mkhumbane" was due open in Durban's City Hall on 28 March 1960. As the opening night approached, South Africa was engulfed by momentous events: on 20 March, 69 protestors on a PAC organised march were shot dead by police, in what would become known as the Sharpeville massacre. As tensions in the country mounted, and thousands of people took to the streets, Chief Lutuli, the leader of the ANC, declared 28 March a national day of mourning on which all South Africans were called upon to stay away from work. After some deliberation, the SAIRR decided to heed the call, and the gala opening night of "Mkhumbane" was postponed to the $29^{\text {th }}$, thereby throwing the booking for the rest of the week's run into disarray. The following day, the state was rocked by a massive march of 30 ooo people in Cape Town, led by Philip Kgotsana. White South Africa seemed under siege, but the government then struck back forcefully by declaring a state of emergency on the same day, and arresting over 18000 people in a series of raids (Omer-Cooper, 1988: 209). Among them was Peter Brown, who had earlier taken over the chairmanship of the Liberal Party from Paton. Looking at Paton's lyrics today, one is struck not only by their musical, foot-tapping quality, but also the uncanny way they anticipated the political events unfolding on South Africa's streets at the time:

Thousands and thousands and thousands are marching

The road where the traveller cannot return

Our feet walk the street of the town and the city

These are the ways our children must learn. ( $\mathrm{PC} 1 / 3 / 7 / 8)$

It was in this extraordinary week that "Mkhumbane" ran in Durban, and Paton was fearful that the political turmoil and heightened racial tensions would affect

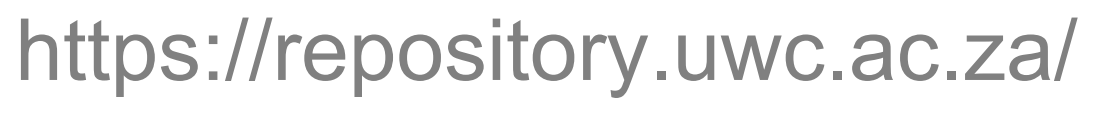


the performance. Instead, as he recounts in his autobiography, "it was a kind of miracle" that in "the whole of South Africa the Durban City Hall was of all places the most untroubled" (1990: 195). Similarly, the show's patron, Archbishop Dennis Hurley, expressed his gratitude "for an event that proclaims South Africa's ability to rise above its division". ${ }^{13}$ The experience of "Mkhumbane" must have shown Paton the transformative power of theatre, and would have strengthened his belief that drama could play a positive role in building a nonracial, integrated society, even under the most trying circumstances. This is how he described the experience to Edward Callan:

During this momentous week we played to full houses, people of all kinds and races, in Durban City Hall. It was indeed a moving experience to go into that hall and see there the absence of all fear and hate. (1968: 33)

The story of "Mkhumbane" is itself fairly conventional and without any overt political message, except that it would have made the white members of the audience aware of the conditions under which black people lived. The plot revolves around the Buthelezi family, whose son, John, wants to become a doctor. These ambitions are thwarted when the father is robbed of the family savings by tsotsis. Later that night, Lindiwe, John's girlfriend, has organised a fund raising party in a shebeen where the stolen purse is miraculously returned, and the tsotsi's routed by the community. The opposing forces in the play are, on the one hand, decent, hard-working folk like the Buthelezis, and on the other hand, the corrupt businessman Mr Charlemagne and his tsotsi gang. Dramatic action takes place between these two sets of black protagonists, and the apartheid government plays a much more peripheral role, in the shape of obstructive "Bantu Affairs" officials who deny a work permit to John Buthelezi, the would be doctor. One of the songs captures the frustrations of dealing with apartheid bureaucracy:

Where are your papers? Your papers? Your papers?

Where were you born? Where were you born?

Who is your chief? Where was your home?

Here is the boy who is looking for work.

No more today, come back tomorrow.

No more today. (PC 1/3/7/8)

Although the play does not overtly castigate the government policies that in the first place produced the crime-ridden social conditions and bureaucratic restrictions such as those depicted in the story, Paton succeeded in depicting the life of ordinary black people in such as manner that showed their lives in a humane and sympathetic light. Most white South Africans, at the time, had little awareness of the conditions under which black workers and their domestic servants lived. "Mkhumbane" depicted township conditions in a realistic and

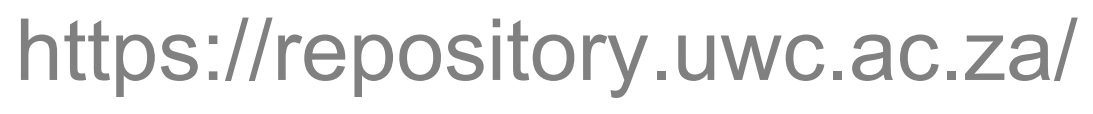


empathetic manner that allowed white viewers to identify with black urban experience on a human level. As Paton told a journalist at the time, "Mkhumbane" was a story of

goodness and evil, sorrow and happiness, beauty and ugliness. It conveys the life, vigour and incredible hope of this slum of the white man's city. (PC 1/3/7/8)

Like the Johannesburg sections of his famous novel, Paton's musical attempted to depict a more complex social reality of life in black urban areas, places that most white South African at the time preferred not to look at too closely.

\section{Sponono}

With the success of "Mkhumbane", Paton had reached a level of maturity and skill as a playwright that would have augured well for future plays and productions. His next musical play, Sponono, indeed had a successful South African run in most major urban centres after its opening in Durban, but the $\$ 125$ ooo New York production, backed by Anglo American, was a spectacular and costly box office disaster. Paton was shaken by the debacle and, having invested $£_{5000}$ in the ambitious venture, lost a considerable sum of his own money. He never wrote another play subsequently. Having been published twice, the text of Sponono has received a fair amount of critical attention by South African theatre historians (Hauptfleisch 1997; Orkin 1991), and this paper will largely confine itself to aspects not discussed before, namely an assessment of the racial politics of the play and their impact on its Broadway failure.

Sponono was a collaboration between Paton and Krishna Shah, a young Indian director who had brought his New York play, "King of the Dark Chamber" to Durban. Shah had read Paton's collection of short stories, titled Debbie go Home (1961), and proposed working three of the stories, namely "Sponono", "Ha' Penny" and "Death of a Tsotsi" into a composite dramatic story. The stories were based on Paton's Diepkloof reformatory experiences and the play revolved around the relationship between a white principal (based on Paton) and an African boy named Sponono. Paton commented on the character as follows:

Sponono was a real person. He was a boy at the reformatory, and an engaging rascal. He was a boy in which good and evil struggled with each other, for he was attracted to them both. (1983: 2)

The titular character is an engaging and charming figure who oscillates between being a reformed young man and someone whose criminality breaks out. The two sides of Sponono are perpetually in competition: the person who virtuously helps

the visiting $\mathrm{Mr}$ and Mrs Makatini, and then, in a changed almost unrecognizable

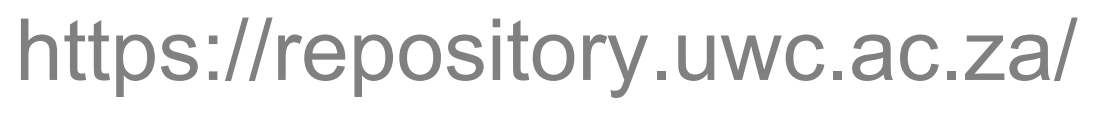


persona, storms back into the waiting room and robs them of 50 pounds; a pupil who shows heartfelt contrition, but then mocks the principal. The role reversals of the character are mirrored in the play itself, when in the last act, there is an imaginary trial at which Sponono presides over the interrogation of the principal, eventually finding him guilty of deserting his post. Despite the play's title, its central character is the virtuous, liberal principal who dispenses compassionate justice. As Sponono's girlfriend Elizabeth puts it "Can't you see that he is the only one in the world that can save you? But you don't want to be saved. You want to be lost" (1983: 144).

Shah and Paton worked together on the script, and Gideon Nxumalo provided the music for the boys' song and dance numbers. Instead of using amateur actors as in "Mkhumbane" and "Last Journey", this time a professional group of black actors, the Union Artists, was engaged. The Union Artists was a group of black performers with origins in Sophiatown whose members provided the cast for several important performances in South Africa, including the "King Kong" musical and some of Fugard's plays. ${ }^{14}$ Sponono opened on 12 December 1962 in Durban's ML Sultan Theatre, and also played in Sea Point's Weizman Theatre before moving to the Lotus Hall in Pietermaritzburg in March of 1963. There were also Johannesburg performances of an uncertain date and place. The names of the theatres in which Sponono performed indicate that the government's segregation campaign was gathering momentum. Mainstream theatres were by now off limits and in 1965 a law formalised the prohibition on all multi-racial gatherings. In the Cape Times (11 March 1963), Ivor Jones called the play an "exciting dramatic contrivance" that "drew packed multi-racial audience to its opening night". Tony Williams Short, in The Argus (11 March 1963) saw it as a "profound study of the subtleties and depths of forgiveness" that was not about "colour" but had a "universal theme".

While South African critics were largely positive about Sponono, the play's New York run was met with more mixed reviews. Although Howard Taubman in the New York Times (3 April 1964) was largely well-disposed and called the final "ritualistic trial" scene "fantastic and moving", other reviewers disagreed. Walter Kerr in the New York Herald Tribune (3 April 1964) saw much in the play that he thought was "hopeful" but thought that "the last scene falls into contrivance". Similarly, James Chapman of the Daily News (3 April 1964) felt that Sponono was "excitingly and colourfully staged" but that the "philosophical fantasy" of the ending was "a letdown". But what must have been more painful for Paton was the suggestion that the play was Uncle Tom-ish. As he explained later

\section{https://repository.uwc.ac.za/}


Sponono was not a success with the sophisticated black audiences in America. They saw the white principal as a creature of the colonial past of Africa. When he rebuked or punished, he was not rebuking or punishing offences, he was rebuking or punishing black offences. The principal stood out like a sore thumb, the only white actor in an all-black play. (1983: 2)

All the same, the play's failure on Broadway can not be solely attributed to the script, because it subsequently ran successfully on other American stages. After watching a performance in Chicago's Parkway Theatre, Richard Christiansen of the Chicago Daily News, was so impressed by the chorus, exotic drums, shouts and wild dancing that he proclaimed Sponono to be

the damndest piece of theatre to be put on a Chicago stage this year. It is explosive, exciting, exuberant and smashingly singular in the kind of dramatic experience that it offers. (28 Febuary 1966)

The reasons for the Broadway fiasco must therefore not necessarily be sought in the shortcomings of Paton's and Shah's script, but in the acrimonious climate that surrounded the musical's production. An exchange of increasingly angry and desperate letters between the formidable Mary Frank (the New York producer), Krishna Shah (who directed), and Paton testify to the looming debacle. In a letter dated less than ten days before the opening night (23 March 1964, PC 1/1/8/6), Mary Frank wrote to Paton that she was convinced that the show was "headed for certain disaster". She expressed her dissatisfaction with Shah, blaming him of being "so emotionally close to this entire play that he has lost his ability to look objectively". The Union Artist actors from South Africa, she opined, did not meet the standards of New York's "sophisticated audiences": in order to succeed with the play, it "would take actors of enormous experience and tremendous professional skill, which these people have not had the opportunity to acquire." She also took a swipe at the script: "I found that the play had no flow, everything was spotted on individual scenes and we had a very episodic play."

Shah in turn wrote a long, tearful letter to Paton (6 April 1964, PC 1/1/8/6) in which he bitterly complained of his "hurt and shock by the course of events" that left him feeling "ten years older". It appears that Mary Frank increasingly intervened in Shah's direction, constantly demanding major changes. Shah wrote of "shouting matches", and that "she had really gone wild". Frank apparently wanted more "bantu music" and "tribal costume" in the play wherever possible. Although increasingly unhappy, Shah claimed that he obliged out of concern for the cast. Finally though, a few days before the opening night, matters came to a head when she summarily sacked Shah, and sent him a lawyer's letter ordering

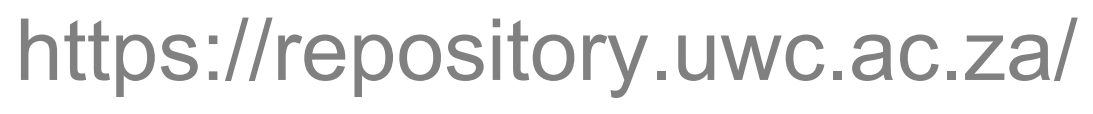


him to stay in his hotel room. Giving out publicly that Shah was sick, Frank then moved swiftly to stamp her authority on the production by postponing the opening night by three days and taking over direction personally.

Paton wrote a sympathic but non-committal letter to Shah, assuring him that he was not talking sides, but admitting "that something went badly wrong with Sponono" (14 April 1964: PC 1/1/8/6). In any event, Paton was unable to intervene, because he had no passport, though Mary Frank wrote a simultaneously obsequious and haughty letter to Jan de Klerk, the South African Interior Minister, demanding Paton's confiscated passport to returned (PC $1 / 1 / 8 / 5)$.

Under these poisoned circumstances, it is not surprising that Sponono fared badly and ran to increasingly emptier houses after it finally opened in the Cort Theatre on 2 April 1964. From the correspondence cited above, it appears that Mary Frank was the villain in the affair. Her domineering and imperious personality is certainly apparent in an extraordinary advertisement that she took out in the New York Times (15 April 1964). The text is a condescending and patronizing lecture haranguing the theatre-going public, but ends with a curious mixture of pleading and black mail. It is cited here in full as a textbook example of how to insult and alienate one's audience:

\section{"Sponono"}

It has long been my assumption that the theatre is not only a mecca for just entertainment, but also a meeting place for the thoughtful, where stimulation and inspiration may be found, and enjoyed.

I produced "Sponono", a play that provides these particular qualities of theatre. The critics received "Sponono" with dignified attention and considerable satisfaction.

Where, though, are the theatregoers who bring their minds to the theatre? Where are the liberals? Where are the Negroes? Where is the thinking audience that should care, must care? They are far from the box-office of the Cort Theatre, as though in concert? Is there an arranged boycott?

Diplomats and clergymen find "Sponono" a challenge, vital and meaningful. They appreciate what co-authors Alan Paton and Krishna Shah are saying about South Africa. They have said so, loud. But those who should be leading the parade to "Sponono" are not only not there ... they have never been heard from. Where are they? Why? What have they to say?

\section{https://repository.uwc.ac.za/}


If they do not come forth with support, and attention, before next Saturday, "Sponono" will not be here for them, or you, to see, and savor, ever again.

\section{-- Mark K. Frank}

From the tone of Mary Frank's ill-advised advertisement, it is no surprise that New York's audiences did not heed her call, and that Sponono was forced to close prematurely, on 18 April 1964. Paton was sufficiently embarrassed by the affair that he left out any mention of the play in his autobiography.

\section{Conclusion}

A careful look at Paton's plays shows that he made considerable advances in developing his theatrical craft, moving from an initial formal conception of theatre played on conventional proscenium stages ("Louis Botha", "Last Journey") to a more hybrid and mobile form of performance that incorporated dance, music and song ("Mkhumbane", Sponono). A comparison of the photographs of scenes from "Last Journey" and "Mkhumbane", clearly shows this transition from static tableau-like theatre to integrated, lively action (Fig. $2 \& 3$ ).

But Paton's dramatic writing will inevitably be compared to Athol Fugard's highly successful play writing career and his more radical conception of theatre. Given the sharp aesthetic and theatrical differences in the work of these two playwrights, it is not surprising that Fugard was among Paton's sharpest critics. Under the influence of his recent encounter with Beckett, Fugard wrote about his meeting with Paton in January 1963:

I could not really talk to him about theatre because he knows nothing about the medium. Incredibly naïve - a naivety at the level of tools, craftsmanship, of realising what can be done on stage, of what has been done. Ignorant even of what is possible with his own plays, like Sponono. (1983: 68-9)

Paton would no doubt have disagreed with Fugard's damning indictment, but he was, all the same, also modest about his own theatrical ability. In his autobiography he wrote: "I have no pretensions to be a playwright" (1990: 195). On the evidence of the plays discussed in this article, Fugard's private assessment of Paton's stagecraft is clearly unduly negative and exaggerated, especially if we read that he also thought that T.S. Eliot was "ignorant of theatre and its meaning" (1983: 78).

How then do we then finally assess Paton's work for the stage? It is evident that his theatrical work was a varied body of serious work that achieved considerable

$$
\text { https://repository.uwc.ac.za/ }
$$


local and international critical success, and also made a pioneering contribution towards non-racial theatre in South Africa. While none of Paton's plays has had the enduring success of his first novel, Cry, the Beloved Country, his theatrical writing is an important if uneven and sometimes flawed body of work that shows him using the stage in creative ways to advance liberal and progressive ideas about South African society, and above all, spread his message of interracial harmony and reconciliation. Looking at Paton's theatrical output as a whole, we see an accomplished writer who saw theatre as a vital tool to shape public perception and advance a programmatic liberal vision of a post-racial society. 


\section{Notes}

${ }^{1}$ Alan Paton's unpublished and undated "Essay - The Last Journey", PC 1/3/6/3. All PC references refer to manuscripts held in the Alan Paton Centre, University of KwaZulu Natal, Pietermaritzburg.

1. Susan VanZanten Gallagher has traced the rise and fall of Paton as follows:

"Enthusiastically received by many black South Africans in the fifties, Cry, the Beloved Country's critical stock fell throughout the seventies and the eighties with the advent of the Black Consciousness movement. Noted authors such as Mphahlele, Nkosi, and Dennis Brutus derided the novel's stereotyped African characters, naive political stance, and apparent paternalism" (1997: 384).

1 "Lost in the Stars" played on Broadway between 30 October 1949 to 1 July 1950. It was restaged and ran for another month in 1972. Source: Internet Broadway Database, http://www.ibdb.com.

${ }^{1}$ See Peter Alexander's Alan Paton (1994), pp 112 - 3.

${ }^{1}$ The judges comments are contained in a letter that was found inside the returned script (PC 1/3/4).

${ }^{1}$ See Paton's Towards the Mountain (1980: 209-210).

1. Paton's journey is briefly mentioned in Peter Alexander's biography (1994: 311).

1 "Alan Paton watches rehearsals", Central African Post, 29 May 1959.

${ }^{1}$ The constitution's wording is taken from membership cards belonging to the Patons. Alan and his wife Dorrie joined as honorary life members 107 and 108 respectively. Apart from the amateur theatrical group, the Waddington Players, the Waddington Club also had badminton, table tennis, folk dancing, photography and radio clubs. Because it functioned under the auspices of the local Anglican church, the club only had a "dry canteen."

1 This and following quotations are from Paton's "Essay - The Last Journey", PC 1/3/6/3.

1 “Alan Paton watches rehearsals" Central African Post, 29 May 1959.

${ }^{1}$ Peter Alexander writes that Paton was dissuaded from pursuing his ambitions with the play by his New York agent Annie Laurie Williams. Alexander briefly discusses the Livingstone play, but confuses the two versions when he states that the Lusaka premiere was staged in a cathedral (1994:314).

1 "Foreword" in souvenir programme, PC 1/3/7/8.

${ }^{1}$ For brief discussion of the history and impact of the Union Artists, see Orkin (1991: 72-73). 


\section{Works Cited}

Alexander, Peter. 1994. Alan Paton. A Biography. Oxford: Oxford University Press.

Callan, Edward. 1968. "Alan Paton and the Liberal Party". In Alan Paton The Long View. Ed. Edward Callan. London: Pall Mall Press.

Fugard, Athol.1983. Notebooks 1960 - 1977. Johannesburg: AD. Donker.

Hauptfleisch, Temple. 1997. Theatre and Society in SA. Reflections in a Fractured Mirror. Pretoria: Van Schaik.

Omer-Cooper, J.D. 1988. History of Southern Africa. Cape Town: David Phillip.

Orkin, Martin. 1991. Drama and the South African State. Manchester: Manchester University Press.

Paton, Alan. 1932. "Louis Botha". Unpublished mss: PC 1/3/4.

—. 1949. "A Light Comedy". Unpublished mss: PC 1/3/4/7

—. 1961. Debbie Go Home. London: Jonathan Cape.

-. 1968. The Long View. Ed. Edward Callan. London: Pall Mall Press.

—. 1971. "Chess in Yugoslavia". South African Outlook, December: 190-192.

—. 1980. Towards the Mountain. Harmondsworth: Penguin.

—. 1983. Sponono. With Krishna Shah. Cape Town: David Phillip.

- 1988 (1948). Cry, the Beloved Country. Harmondsworth: Penguin.

—. 1990. Journey Continued. Harmondsworth: Penguin.

—. n.d. "The Last Journey". Unpublished mss: PC 1/3/6/2

-. n.d. "David Livingstone. Being a dramatic representation of the life of the great missionary and explorer, designed for performance in churches". Unpublished mss: PC 1/3/6/5.

-. n.d. "Essay - The Last Journey". Unpublished mss: PC 1/3/6/3

—. n.d. "Mkhumbane". Unpublished mss: PC 1/3/7/8

Vanzanten Gallagher, Susan. 1997. "The backward glance: history and the novel in post-apartheid South Africa". Studies in the Novel. 29/3 (Fall): 376 -386.

Walder, Dennis. 1984. Athold Fugard. London: Macmillan.

Watson, Stephen. 1982. "Cry, the Beloved Country and the Failure of Liberal Vision". English in Africa 9 /1 (May): 29 - 44.

Wittenberg, Hermann. 2005. "Introduction”. In Alan Paton Lost City of the Kalahari. Ed. H. Wittenberg. Pietermaritzburg: UKZN Press.

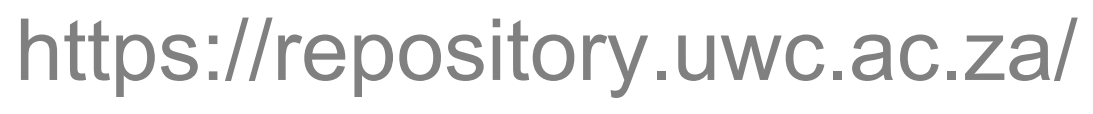

